\title{
PROGRAM PENGUATAN KARAKTER MUSYRIF DI PONDOK PESANTREN MODERN
}

\author{
Matnur Ritonga, Hasbi Indra, Budi Handrianto \\ 1,2,3 Universitas Ibn Khaldun \\ email: matnurcritonga@gmail.com
}

\begin{abstract}
ABSTRAK
Eksistensi pondok pesantren sebagai lembaga pendidikan Islam menjadi solusi kebutuhan masyarakat khususnya orangtua dalam membina dan mendidik akhlak dan karakter anak-anaknya. Apalagi belakangan tantangan dan situasi lingkungan sosial sangat mengkhawatirkan sehingga bila tidak waspada dapat mendistorsi perilaku anak. Untuk itu di dalam pondok pesantren dibutuhkan para musyrif yang berkarakter mandiri. Tujuan penelitian ini ingin membuat program penguatan karakter musyrif/musyrifah yang ideal di pondok pesantren. Data penelitian dikumpulkan melalui observasi, wawancara, studi dokumentasi, dan studi kepustakaan. Teknik analisis data dengan cara reduksi data, penyajian data, penarikan kesimpulan dan verifikasi. Hasil penelitian menunjukkan bahwa program penguatan karakter musyrif yang ideal di pondok pesantren adalah: a) Pengarahan ke-musyrifah-an di awal penugasan, b) Mukim di asrama harus secara kaffah, c) Alat transportasi dan telekomunikasi harus dibatasi, c) Harus ada buku panduan musyrif, d) Rapat evaluasi mingguan dengan Pengasuh, e) Pendokumentasian reward and punishment, f) Uswatun-hasanah dari Pengasuh meliputi: Mengajar, mengimami shalat jama'ah, sesekali berkegiatan bersama musyrif, berbahasa resmi saat berinteraksi dengan musyrif, bermukim dan berkantor di dalam pondok, hadir dalam berbagai macam kegiatan.
\end{abstract}

Kata kunci: program penguatan, karakter, musyrif.

\section{INTRODUCTION}

Dalam skala makro dunia abad 21 sekarang ditandai oleh 6 (enam) kecenderungan penting, yaitu (a) revolusi digital yang semakin mengubah sendi-sendi kehidupan, kebudayaan, peradaban, dan kemasyarakatan termasuk pendidikan, (b) integrasi belahan-belahan dunia yang semakin intensif akibat internasionalisasi, globalisasi, hubungan-hubungan multilateral, teknologi komunikasi, dan teknologi transportasi, (c) pendataran dunia (the world is flat) sebagai akibat berbagai perubahan mendasar dimensi-dimensi kehidupan manusia terutama akibat mengglobalnya negara, korporasi, dan individu, (d) perubahan dunia yang mengakibatkan dunia tampak berlari tunggang langgang, ruang tampak menyempit, waktu terasa ringkas, dan keusangan segala sesuatu cepat terjadi, (e) tumbuhnya masyarakat padat pengetahuan (knowledge society), masyarakat informasi (information society), dan masyarakat jaringan (network society) yang membuat pengetahuan, informasi, dan jaringan menjadi modal sangat penting, dan (f) makin tegasnya fenomena abad kreatif beserta masyarakat kreatif yang menempatkan kreativitas dan inovasi sebagai modal penting untuk individu, perusahaan, dan masyarakat (Kemdikbud, 2017:1).

Dalam skala mikro pendidikan, dunia abad 21 sekarang juga ditandai oleh adanya imperatif-imperatif global pendidikan, di antaranya Pendidikan untuk Semua (PUS), 
Pendidikan bagi Pembangunan Berkelanjutan (ESD), Tujuan Pembangunan Milenium (MDG's), dan Literasi Dunia bagi Pemberdayaan. Selain itu, juga ditandai oleh munculnya temuan-temuan dan pemikiran-pemikiran baru yang berkenaan dengan dimensi tertentu pendidikan, di antaranya temuan neurosains pendidikan dan pembelajaran (misalnya hubungan otak dan belajar), munculnya pelbagai teori kecerdasan, tumbuhnya pemikiran baru pembelajaran (misalnya blended learning, mindful learning), dan kebijakan baru bidang pendidikan dan pembelajaran. Lebih jauh lagi, juga muncul pergeseran peranan dan fungsi pendidikan dalam masyarakat, tugas pranata dan lembaga pendidikan, dan bentuk organisasional pendidikan serta keberadaan modal manusia dalam pendidikan. Hal tersebut menimbulkan konsekuensi tantangan, tuntutan, dan kebutuhan baru dalam sendi-sendi pendidikan (Kemdikbud, 2017:2).

Munculnya berbagai fenomena sosial yang memprihatinkan akhir-akhir ini mendorong pemerintah untuk merumuskan Kebijakan Nasional Pembangunan Karakter Bangsa, dimana Pembangunan karakter bangsa dijadikan arus utama pembangunan nasional. Hal ini dimaksudkan bahwa setiap pembangunan yang dijalankan akan berdampak positif bagi pengembangan dan pembentukan karakter bangsa. Dalam perspektif Islam, Pendidikan Karakter merupakan upaya untuk mengembangkan keseluruhan aspek kemanusiaan manusia dalam dimensi fisik jasmani, emosi, spiritual dan intelektual, untuk menghasilkan pribadi yang memiliki karakter beriman, bertanggungjawab, peduli, jujur, berani dan menjadi warga negara yang baik. Model penanaman nilai karakter melalui pengajaran, pembiasaan, peneladanan, pemotivasian dan penegakan aturan yang diimplementasikan secara konsisten dan berkesinambungan dalam keseharian di rumah, sekolah maupun di masyarakat akan membentuk individu berkarakter unggul, sebagai khalifah fi al-Ardhi (Aan Hasanah, 2014:186).

Sulaiman Efendi (2018) mengatakan bahwa eksistensi pondok pesantren sebagai lembaga pendidikan Islam menjadi solusi kebutuhan masyarakat khususnya orangtua dalam membina dan mendidik akhlak dan karakter anakanaknya. Apalagi belakangan tantangan dan situasi lingkungan sosial sangat mengkhawatirkan sehingga bila tidak waspada dapat mendistorsi perilaku anak.

Pengasuh pondok pesantren melibatkan musyrif dalam mengasuh, mengontrol, membimbing, memotivasi, dan mengevaluasi santri dalam berkegiatan selama 24 jam. Namun pada kenyataan di lapangan, masih didapati musyrif yang belum mandiri dalam melaksanakan tugas ke-musyrifah-an. Masih adanya kekerasan yang dilakukan oleh para pengurus organisasi terhadap adik kelasnya. Hal ini merupakan dampak dan bukti dari kurang kontrol. Jarangnya musyrif membimbing klub sehingga mengakibatkan ada klub 
yang tidak berjalan. Seringnya musyrif terlambat dalam berbagai kesempatan untuk membimbing kegiatan yang ada, dan lain sebagainya. Untuk itu dibutuhkan para musyrif yang berkarakter mandiri di pondok pesantren.

Pengembangan Sumber Daya Manusia (SDM) di pondok pesantren harus mengacu dan berdasar atas prinsip keikhlasan, kemandirian, kebebasan, kesejahteraan, dan ukhuwah islamiyah agar tercipta ukhuwah islamiyah, ukhuwah basyariyah, dan ukhuwah wathaniyah (A. Halim etal, 2005:63).

Nuraly Masum Aprily (2019) dari Universitas Pendidikan Indonesia meneliti pendidikan karakter di Pesantren Cipari Kabupaten Garut. Hasil penelitiannya menunjukkan bahwa program pendidikan akhlak di pesantren Cipari meliputi: Nidzhom Al-Ma'hadi; kegiatan pembiasaan; pemberian penghargaan (reward) bagi santri yang berprestasi; dan pendidikan 24 jam. Hasil penelitian Akbar (2017) dari Universitas Islam Negri (UIN) Alauddin Makasar menunjukkan bahwa Upaya As'adiyah dalam melakukan peneguhan pendidikan karakter sejatinya sudah dilakukan sejak berdirinya pesantren. Upayanya antara lain; dibentuknya Majlis Al-Qurra' wa Al-Huffazh As'adiyah, lembaga pengkaderan ulama Ma'had 'Ali As'adiyah, tata tertib santri/santriwati, pengajian kitab kuning, pemisahan antara santri laki-laki dan perempuan, pengadaan asrama, kantin kejujuran, muatan lokal ke-As'adiyah-an, dan Radio Suara As'adiyah. Penelitian Safaruddin Yahya (2016) dari UIN Maulana Malik Ibrahim mengenai model pendidikan karakter di pondok pesantren modern al-Syaikh Abdul Wahid Baubau meliputi enam hal, yaitu pendidikan Boarding School dengan pengawasan 24 jam, penegakan disiplin, membiasakan santri mengikuti beragam kegiatan, keteladanan dari diri guru, reward and punishment, pembelajaran dengan model contextual teaching learning (CTL).

Ajat Sudrajat (2011) dari Universitas Negeri Yogyakarta, di dalam Jurnal Pendidikan Karakter menyimpulkan bahwa strategi pelaksanaan pendidikan karakter di sekolah dapat dilakukan melalui empat cara, yaitu: (1) pembelajaran (teaching), (2) keteladanan (modeling), (3) penguatan (reinforcing), dan (4) pembiasaan (habituating). Hasan Baharun (2017) dalam penelitiannya dengan judul “Total Moral Quality, Pendekatan Baru Pendidikan Karakter di Pesantren” membuat kesimpulan bahwa pendidikan karakter dapat diimplementasikan melalui empat figur berikut; Moral modeling, Moral knowing, Moral feeling, 
Moral habituation. Dalam penelitian tersebut juga Hasan Baharun menyimpulkan bahwa pondok pesantren Nurul Jadid sukses dalam menerapkan konsep Total Moral Quality (TMQ). Chusnul Muali dan Robiatul Aini dari Universitas Nurul Jadid dengan judul "Total Moral Quality Sebagai Konsep Pendidikan Karakter di Pesantren; Sebuah Kajian Kritis Pemikiran Hasan Baharun". Pondok pesantren Nurul Qur'an Kraksaan Probolinggo lebih mengikuti kepada pendapat Thomas Lichona, yang mengembangkan ketiga aspek kecerdasan yang ada pada peserta didik, yaitu kognisi melalui moral knowing, afeksi melalui moral feeling, dan psikomotorik melalui moral action. Sedangkan pondok pesantren Nurul Jadid Paiton Probolinggo adalah konsep Total Moral Quality (TMQ) pengembangan dari teori Thomas Lickona, yaitu ; moral modeling, moral knowing, moral feeling dan moral habituation yang dilaksanakan secara terpadu dalam aplikasinya.

Tujuan penelitian ini adalah: Pertama, menganalisis program penguatan karakter musyrif di pondok pesantren Annur Darunnajah 8 Bogor dan pondok pesantren La Tansa Banten. Kedua, setelah menganalisis program penguatan karakter dari kedua lembaga, kemudian dibuat program penguatan karakter musyrif yang ideal di pondok pesantren.

\section{METHOD}

Penelitian yang dilakukan penulis adalah penelitian kualitatif. Menurut Lexy J. Moleong (2010:6), penelitian kualitatif yaitu penelitian yang bermaksud untuk memahami fenomena tentang apa yang dialami oleh subjek penelitian. Penelitian ini tergolong jenis penelitian kualitatif deskriptif (Burhan Bungin, 2011:24), karena penelitian ini memberikan gambaran tentang hasil penelitian dengan mendeskripsikan data aktual yang diperoleh di lapangan yaitu di pondok pesantren Annur Darunnajah 8 Bogor dan pondok pesantren La Tansa Banten. Dalam penelitian kualitatif, yang menjadi instrumen atau alat penelitian adalah peneliti itu sendiri. Peneliti kualitatif sebagai human instrument, berfungsi menetapkan fokus penelitian, memilih informan sebagai sumber data, melakukan pengumpulan data, menilai kualitas data, analisis data, menafsirkan data dan membuat kesimpulan atas temuannya (Sugiyono, 2011:305).

Maka peneliti melakukan langkah-langkan yaitu: pertama melakukan observasi di dua lokasi, kedua mewawancara Kiai, musyrif, dan santri, ketiga studi dokumentasi, keempat 
triangulasi atau gabungan dari ketiga langkah sebelumnya. Teknik analisis data yang digunakan dalam penelitian ini adalah secara manual dengan model Logical Analysis/Matrix Analysis (Miles \& Huberman), yaitu dengan cara: Pengumpulan data. Reduksi data; Transformasi data kasar yang didapat dari lapangan. Penyajian data; Semua data dianalisis sehingga memunculkan deskripsi. Menarik kesimpulan (Sugiyono, 2011:338).

Dalam penelitian kualitatif digunakan empat kriteria, yaitu kredibilitas, keteralihan, kebergantungan, dan kepastian, yang cara pengujiannya berbeda dengan penelitian kuantitatif. Uji kredibilitas data dilakukan dengan cara-cara: perpanjangan pengamatan, peningkatan ketekunan pengamatan, triangulasi, pengecekan teman sejawat, pengecekan anggota, analisis kasus negatif, kecukupan referensi (Nusa Putra, Santi Lisnawati, 2012:3334). Maka untuk kepercayaan, peneliti memperpanjang pengamatan di La Tansa dengan datang ke lokasi tiga kali dan bermalam di sana, sedangkan di ponpes Annur peneliti sudah bermukim di sini selama 10 tahun. Peneliti juga melakukan diskusi dengan teman sejawat; di pondok pesantren Annur dengan Muhamad Towil Akhirudin, dan di pondok pesantren La Tansa Parakansantri Banten dengan Ahmad Rizky.

Untuk kepastian data, peneliti mengonfirmasikan data dengan para informan atau informan lain yang kompeten. Konfirmabilitas dilakukan bersamaan dengan pengauditan dependabilitas. Perbedaannya terletak pada orientasi penilaiannya. Jadi, konfirmabilitas tertuju untuk menilai hasil penelitian yang didukung oleh bahan-bahan yang tersedia terutama yang berkaitan dengan deskripsi, temuan penelitian, dan pembahasan temuan penelitian. Demi konfirmabilitas penelitian ini, peneliti dibimbing oleh Hasbi Indra dan Budi Handrianto.

\section{RESULTS}

Hasil penelitian menunjukkan bahwa program penguatan karakter musyrif yang dilakukan oleh pondok pesantren Annur Darunnajah 8 yaitu: a) pembekalan guru baru, akan tetapi masih bersifat umum karena dilaksanakan di Darunnajah Jakarta, b) Mukim di asrama, c) Pembiasaan (habituation) dalam kehidupan keseharian dengan model kursi tiga kaki yaitu competent, responsible, appreciate, d) Menolong diri sendiri (self help) dengan sistem berjenjang dan berkonfigurasi musyrif-pengurus organisasi-santri, e) Reward and Punishment, f) Uswatun-hasanah dari Kiai. 
Program penguatan karakter musyrif yang dilakukan oleh pondok pesantren La Tansa yaitu: a) Mukim di asrama, b) Polarisasi pola asuh, c) Dewan bujangan gadis (Debus), d) Penegakan disiplin dengan adanya reward and punishment, e) Teladan dari Sang Kiai.

Setalah didapatkan program yang ada di dua lembaga lalu dianalisis dan dipadukan dari masing-masing lembaga sehingga menghasilkan program penguatan karakter musyrif yang ideal di pondok pesantren yaitu: a) Pengarahan secara khusus kepada musyrif di awal penugasan, b) Mukim di asrama harus: (1) secara total (kaffah), (2) Organisasi mudabbir harus tetap ada, (3) Fasilitas kamar mandi, ruang makan, masjid harus representatif, (4) Kepemilikan alat transportasi dan alat telekomunikasi harus dibatasi, c) Ada buku pegangan atau buku panduan standar musyrif, d) Dewan bujangan gadis atau perkumpulan tiap pekan dengan Pengasuh, e) Pendokumentasian reward and punishment, f) Uswatunhasanah dari Pengasuh mencakup: (1) Turut serta dalam kegiatan belajar mengajar, (2) Mengimami shalat jama'ah di masjid, (3) Ikut berkegiatan (kokurikuler ataupun ekstrakurikuler) bersama musyrif walaupun hanya sesekali, (4) Berusaha menggunakan bahasa resmi (bahasa Arab dan bahasa Inggris) saat berinteraksi dengan musyrif, (5) Menetap dan berkantor di tempat strategis di dalam (di tengah-tengah) pondok pesantren, (6) Hadir dalam berbagai macam kegiatan santri seperti: Laporan Pertanggungjawaban (LPJ), Pagelaran seni Panggung Gembira (PG), Perkemahan, dan lain sebagainya.

\section{DISCUSSION}

Pendidikan karakter sangat penting bagi seorang manusia semenjak ia lahir hingga ia dewasa, bahkan sampai ia berkeluarga. Dalam diri setiap individu ada karakter yang melekat, dalam sebuah komunitas ada karakter yang dianut, bahkan bagi sebuah bangsa pun harus ada karakter tertentu yang bisa dijadikan tolok ukur agar dapat dikatakan bahwa bangsa itu berkarakter. Demikian juga akan pentingnya program penguatan karakter musyrif di pondok pesantren, di mana mereka lah yang menjadi tulang punggung pendidikan di luar kelas. Karena mereka lah yang bersentuhan langsung dengan santri dalam beragam aktivitas keseharian.

Rumusan agar manusia Indonesia berkarakter telah dirumuskan sejak Undang-Undang Dasar tahun 1945. Lebih mengerucut lagi bahwa rumusan tersebut termaktub di dalam tujuan pendidikan, yaitu membangun manusia religius, cerdas, dan nasionalis, seperti dalam Undang-Undang Sistem Pendidikan Nasional UU No. 4 Tahun 1950 jo.UU No. 12 Tahun 1954 tentang dasar-dasar pendidikan dan pengajaran di sekolah. Pasal 3 
merumuskan bahwa tujuan pendidikan dan pengajaran adalah "membentuk manusia susila yang cakap, warga negara yang demokratis, bertanggung jawab atas kesejahteraan masyarakat dan tanah air”. UUSPN No. 2 Tahun 1989 menjelaskan bahwa pendidikan nasional bertujuan: Mencerdaskan kehidupan bangsa dan mengembangkan manusia Indonesia seutuhnya, yaitu manusia yang beriman dan bertakwa kepada Tuhan Yang Maha Esa dan berbudi pekerti luhur, memiliki pengetahuan dan keterampilan, sehat jasmani dan rohani, kepribadian yang mantap dan mandiri serta rasa tanggung jawab kemasyarakatan kebangsaan (Bagus Mustakim, 2011: 49).

Setelah reformasi muncul UUSPN No. 20 tahun 2003 pasal 3, yang berbunyi: Pendidikan nasional berfungsi mengembangkan kemampuan dan membentuk karakter serta peradaban bangsa yang bermartabat dalam rangka mencerdaskan kehidupan bangsa, bertujuan untuk berkembangnya potensi peserta didik agar menjadi manusia yang beriman dan bertakwa kepada Tuhan Yang Maha Esa, berakhlak mulia, sehat, berilmu, cakap, kreatif, mandiri dan menjadi warga negara yang demokratis, serta bertanggung jawab (Fokus Media, 2010:6). Ki Hadjar Dewantara dengan Taman Siswanya mengemukakan beberapa hal yang harus dilaksanakan dalam pendidikan karakter, yakni ngerti, ngerso, nglakoni, atau menyadari, menginsyafi, dan melakukan (Y. Suyitno, 2009). Atau yang lebih popular sekarang dengan olah hati, olah pikir, olahraga, olah rasa dan karsa.

Dalam publikasi Pusat Kurikulum Badan Penelitian dan Pengembangan Kementrian Pendidikan Nasional berjudul Pedoman Pelaksanaan Pendidikan Karakter (2011), telah mengidentifikasi 18 nilai pembentuk karakter yang merupakan hasil kajian empirik Pusat Kurikulum yang bersumber dari agama, Pancasila, budaya dan tujuan pendidikan nasional. 18 Nilai-nilai tersebut adalah: Religius, jujur, toleransi, disiplin, kerja keras, kreatif, mandiri, demokratis, rasa ingin tahu, semangat kebangsaan, cinta tanah air, menghargai prestasi, bersahabat/komunikatif, cinta damai, gemar membaca, peduli lingkungan, peduli sosial, tanggung jawab. Ada lima nilai utama karakter yang saling berkaitan membentuk jejaring nilai yang perlu dikembangkan sebagai prioritas gerakan PPK. Kelima nilai utama karakter bangsa yang dimaksud adalah: Religius, nasionalis, mandiri, gotong-royong, integritas (TimPenyusun PPK:8-9).

Menurut Ridjaluddin (2014:17) Jika persoalan moral (karakter bangsa), mental bangsa atau akhlak sudah diselesaikan, barulah bisa membangun sebuah masyarakat tertib, aman, dan sejahtera, gemah ripah loh jinawi tata tentram kerto raharjo. Adian Husaini (2010:149) menyatakan bahwa menjadi manusia, apalagi seorang muslim tidak boleh 
setengah-setengah, harus totalitas agar menjadi manusia yang terbaik, sesuai tujuan awal penciptaannya, pertama sebagai 'abdun (hamba), kedua sebagai khalifah (pemimpin). Bung Karno dalam Muchlas Samani (2011:2) sejak awal mengingatkan bahwa bangsa ini harus dibangun dengan mendahulukan pendidikan karakter (character building) karena pembangunan karakter akan membuat Indonesia menjadi bangsa yang besar, maju, dan jaya, serta bermartabat. Kalau pembangunan karakter tidak dilakukan, maka bangsa Indonesia akan menjadi bangsa kuli.

Kemandirian mencakup kemandirian emosional, kemandirian tingkah laku, dan kemandirian nilai. Kemandirian emosiaonal berhubungan dengan perubahan kedekatan emosional antar individu, seperti hubungan anak dengan orang tua. Kemandirian tingkah laku adalah kemampuan untuk membuat keputusan tanpa bergantung kepada orang lain dan melakukannya secara bertanggung jawab. Sedangkan kemandirian nilai adalah kemampuan memaknai prinsip tentang benar dan salah terhadap apa yang penting dan apa yang tidak penting. Islam menganjurkan umatnya agar mandiri, sehingga setiap upaya ke arah kemandirian mendapatkan porsi penting dalam ajaran Islam. Rasulullah dalam hadits riwayat l-Bukhari, Muslim, l-Tirmidzi dan l-Nasai memberi sugesti kepada umatnya "Sesungguhnya seorang dari kalian pergi mencari kayu bakar yang dipikul di atas pundaknya itu lebih baik daripada meminta-minta kepada orang lain, baik diberi atau tidak”(Muti Ali etal, 2014: 212).

Rasulullah adalah seorang yang sangat mandiri. Beliau sejak kecil dikenal sebagai pekerja keras, di masa kecil beliau menggembala kambing milik salah seorang penduduk Makkah dengan upah yang beliau gunakan untuk bertahan hidup, kemudian setelah dewasa memasuki umur ke-19 beliau berdagang ke Syam. Beliau tak segan mengerjakan pekerjaan sebagaimana dikerjakan orang kebanyakan. Beliau sering menambal sendiri jubahnya, menjahit sepatunya dan melakukan pekerjaan rumah tangga. Suatu hari Rasulullah dan para sahabatnya bepergian dan memutuskan untuk berkemah. Ketika hendak mengolah makanan, mereka berebut untuk ambil bagian. Salah seorang berkata, "Aku yang menyembelih kambingnya". Yang lain berkata, "Aku yang mengulitinya". Rasulullah tidak mau kalah dan beliau berkata, "Aku yang mencari kayu bakarnya”. Beliau pun bergegas meninggalkan para sahabat menuju padang pasir untuk mengumpulkan kayu bakar (Mukti Ali etal, 213-214).

Pelaksanaan Sarasehan Nasional Pendidikan Budaya dan Karakter Bangsa yang dilaksanakan di Jakarta tanggal 14 Januari 2010, telah mencapai Kesepakatan Nasional 
Pengembangan Pendidikan Budaya Dan Karakter Bangsa yang menyatakan bahwa dalam implementasinya, pendidikan karakter dilaksanakan dengan dua strategi utama, yaitu strategi konteks makro, yang berskala nasional, dan strategi konteks mikro, yang berskala lokal atau satuan pendidikan (Abdul Majid dan Dian Andayani, 2011:38).

Jauh sebelum Sisdiknas lahir dan Penguatan Pendidikan Karakter (PPK), sistem pendidikan pondok pesantren sudah ada sebelumnya, yang merupakan sistem pendidikan tertua dan asli (indigenous) di Indonesia, yang mempunyai ciri khas tersendiri dan telah menghasilkan ulama besar dan tokoh-tokoh nasional. Perkembangan zaman melahirkan perubahan-perubahan di masyarakat sekaligus mengubah pola dan sistem pendidikan pondok pesantren. Dalam hal sistem pendidikan pondok pesantren modern yang sistematik, lebih efektif dan efisien tanpa menghilangkan ruh dan nilai tradisionalitas dipelopori oleh Pondok Modern Darussalam Gontor (Abdullah Syukri Zarkasyi, 2005:v).

Melihat hasil temuan yang dilakukan oleh H.M. Yunus Abu Bakar (Disertasi UIN Jogja, 2007), juga temuan yang didapati oleh peneliti sendiri di pondok pesantren Annur Darunnajah 8 Cidokom Bogor dan pondok pesantren La Tansa Parakansantri Banten. Maka dapat disimpulkan, baik pondok pesantren Annur Darunnajah 8 Cidokom Bogor sebagai pondok pesantren cabang kedelapan dari pondok pesantren Darunnajah Jakarta maupun pondok pesantren La Tansa Parakansantri Banten, keduanya menganut nilai-nilai dari pondok pesantren Gontor dengan pola Inovasi konstuktif linier.

Menurut Eko Putro Widoyoko (2010:8) program diartikan sebagai serangkaian kegiatan yang direncanakan dengan seksama dan dalam pelaksanaannya berlangsung dalam proses yang berkesinambungan dan terjadi dalam suatu organisasi yang melibatkan banyak orang. Program Penguatan Karakter musyrif di pondok pesantren (modern) sudah sejak awal berdiri dilakukan dengan menyisipkan kegiatan-kegiatan yang bertujun untuk menguatkan karakter tersebut di antaranya: menyanyikan lagu Indonesia raya setiap upacara hari Sabtu dan perayaan HUT RI, berdoa bersama pada setiap perkumpulan, tadarus Al-Qur'an sehabis shalat subuh, ashar, dan magrib, literasi, mengaji, shalat dhuha, khatib shalat jum'at, kokurikuler dan ekstra kurikuler. Selain dari itu terkait sarana dan prasarana, Direktur KMI (TMI), Masyayikh, musyrif, keikutsertaan orang tua murid (semisal penerimaan rapot dan perkumpulan awal tahun ajaran dengan pengasuh), merespon positip dan siap untuk melaksanakan kebijakan PPK yang ada. Kemampuan manajerial Kiai untuk menggali potensi lingkungan sebagai sumber belajar dan 
mengembangkan kerja sama dengan berbagai pemangku kepentingan dalam ekosistem pendidikan yang ada sangat dibutuhkan untuk mendukung PPK musyrif.

Tugas-tugas yang diemban para musyrif di asrama cukup berat karena mereka harus memerankan berbagai macam peran, peran sebagai orang tua, peran sebagai sahabat, peran sebagai guru, dan lain sebagainya. Diantara tugas-tugas tersebut adalah: (1) Pengganti ayah dan ibu selama di pesantren. (2) Pengayom bagi santri di asrama. (3) Tempat mencurahkan isi hati (curhat) dan tempat mengadu permasalahan-permasalahan santri. (4) Sebagai mediator (perantara) komunikasi antara santri dengan orang tuanya atau sebaliknya. (5) Memberi rekomendasi untuk izin jika santri ingin keluar pesantren dengan orang tua atau wali. (6) Pembimbing kegiatan harian, mulai dari bangun tidur sampai akan tidur (Darunnajah, 2015:11).

Pondok pesantren Annur Darunnajah 8 Cidokom Bogor dan pondok pesantren La Tansa Parakansantri Banten yang berafiliasi kepada Pondok Modern Darussalam Gontor dalam program penguatan karakter musyrif secara konsisten menganut tiga plus satu berarti empat komponen sistem pendidikan di pondok pesantren yaitu aspek nilai, aspek sistem asrama, aspek materi, aspek sarana dan prasarana (Adrian Mafatihullah Kariem, 2016:9). Aspek nilai setidaknya lima plus empat, jadi ada sembilan pilar peradaban pondok pesantren (panca jiwa dan motto pondok). Panca jiwa pondok pesantren meliputi, 1) keikhlasan, 2) kesederhanaan, 3) kemandirian, 4) ukhuwah islamiyah, 5) kebebasan. Ditambah dengan motto pondok pesantren yaitu, 1) berbudi luhur, 2) berbadan sehat, 3) berpengetahuan luas, 4) berpikiran bebas (Adrian, 2018:99).

Aspek sistem asrama sendiri memiliki lima sub sistem, yaitu; keteladanan, penciptaan lingkungan, pengarahan, pembiasaan, penugasan, dan penegakan disiplin dengan adanya reward and punishment (Abdullah Syukri, 2005:115). Di dalam aspek sistem asrama inilah yang paling banyak menyangkut dengan program penguatan karakter musyrif/musyrifah karena terkait dengan kegiatan kokurikuler dan ekstrakurikuler.

Aspek materi yang dianut pondok pesantren Annur Darunnajah 8 Cidokom Bogor dan pondok pesantren La Tansa Parakansantri Banten menganut sistem integrated yaitu perpaduan ilmu-ilmu keislaman dan ilmu-ilmu umum. Jika dirincikan maka akan tampak terstruktur kepada beberapa bagian yaitu, 1) al-Dirosah al-islamiyah, seperti Aqidah, Fiqh, Tarikh, dan lain sebagainya 2) al-dirosah al-lughowiyah, seperti nahwu, shorf, durusu allughoh, imla', dictation, grammar, dan seterusnya, 3) al-Dirosah al-kauniyah, seperti 
matematika, fisika, kimia, biologi, dan selainnya, 4) Muatan lokal seperti kepesantrenan, nisa'iyah, dan leadership (ada yang diajarkan di dalam kelas, ada yang dinilai melalui praktek keseharian dalam kepemimpinan organisasi santri).

Aspek sarana dan prasarana di pondok pesantren Annur Darunnajah 8 Cidokom Bogor masih banyak yang harus ditambah, seperti ruang makan permanen untuk santri dan guru (musyrif), ruang laboratorium dan perlengkapannya, ruang produksi penerbitan, masjid yang representatif, dan lain sebagainya. Sedangkan sarana dan prasarana di pondok pesantren La Tansa Parakansantri Banten sudah cukup memadai, tinggal maintenance (perawatan) yang harus terus dilakukan.

Penanaman pendidikan kareakter musyrif di pondok pesantren modern melalui lima (5) P dan satu (1) U yaitu: Pengarahan, pelatihan, penugasan, pembiasaan, pengawalan, uswatun-hasanah. Selain $5 \mathrm{P}$ dan $1 \mathrm{U}$ di atas, ditambah lagi dengan tiga pendekatan yaitu: pendekatan manusiawi, pendekatan program, dan pendekatan idealisme.

\section{CONCLUSIONS}

Untuk menjadikan musyrif yang berkarakter mandiri yang di mana subnilai mandiri antara lain etos kerja (kerja keras), tangguh tahan banting, daya juang, profesional, kreatif, keberanian, dan menjadi pembelajar sepanjang hayat. Maka segala daya dan upaya harus dilakukan oleh semua stakeholders yang ada mulai dari Kiai dan guru senior (masyayikh) di pondok pesantren. Upaya yang dilakukan merupakan wujud dari pengejewantahan tujuan pendidikan nasional, yaitu membentuk manusia Indonesia yang berkarakter dan tujuan pendidikan Islam (yang bersumber Al-Qur'an dan al-sunnah) yaitu 'liitmami makarimi al-Akhlaqi”, tidak lain dan tidak bukan kecuali untuk penyempurnaan akhlak manusia.

\section{REFERENCES}

Abu Bakar, M. Yunus. (2007). Konsep Pemikiran Pendidikan K.H Imam Zarkasyi dan Implementasinya pada Pondok Pesantren Alumni, disertasi Doktor pada PPS UIN Sunan Kalijaga Yogyakarta (pdf).

Ali, Mukti, etal. (2014). Pendidikan Karakter Berbasis Tradisi Pesantren. Jakarta: renebook.

Bungin, M. Burhan. (2011). Penelitian Kualitatif, Komunikasi, Ekonomi, Kebijakan Publik, dan Ilmu Sosial Lainnya. Jakarta: Prenada Media Group.

Fadjar Noegraha, Ridjaluddin. (2014). Kajian Sejarah Ki Hadjar Dewantara dan Karakter Bangsa. Ciputat. 
Fadjar Noegraha, Ridjaluddin. (t.t). KH. Imam Zarkasyi dan Modern isasi Pendidikan. Jakarta: FAI UHMKA.

Fokus Media. (2010). Undang-undang Sistem Pendidikan Nasional. Bandung: Fokus Media.

Halim, A. et.al. (2005). Manajemen Pesantren. Yogyakarta: PT LKiS Pelangi Aksara.

Husaini, Adian. (2016). 10 Kuliah Agama Islam (Panduan Menjadi Cendekiawan Mulia dan Bahagia). Yogyakarta: Pro-U Media.

Mafatihullah Kariem, Adrian. (2018). Suara Bestari Pesan-pesan Trendi (Surabi Pesantren). Jakarta: Republika.

Majid, Abdul, dan Dian Andayani. (2011). Pendidikan Karakter Perspektif Islam. Bandung: PT Remaja Rosdakarya.

Moleong, Lexy J. (2010). Metodologi Penelitian Kualitatif. Bandung: Remaja Rosdakarya.

Mustakim, Bagus, 2011, Pendidikan Karakter, Membangun Delapan Karakter Emas Menuju Indonesia Bermartabat. Yogyakarta: Samudra Biru.

P. Chaplin, James. (2011). Kamus Lengkap Psikologi (Terjemah Oleh: Kartini Kartono). Jakarta: PT Rajagrafindo Persada.

Putra, Nusa dan Santi Lisnawati. (2012). Penelitian Kualitatif Pendidikan Agama Islam, Bandung: PT Remaja Rosdakarya.

Putro Widoyoko, S. EKo. (2010). Evaluasi Program Pembelajaran: Panduan Praktis Bagi Pendidik dan Calon Pendidik. Yogyakarta: Pustaka Pelajar.

Samani, Muchlas, dan Hariyanto. (2011). Konsep dan Model Pendidikan Karakter. Bandung: PT Remaja Rosda Karya.

Siti Aisyah. (2016). Peranan Guru Akidah Akhlak Dalam Pembinaan Karakter Santri di Pondok Pesantren Al-Washliyah Gading Tanjungbalai. Medan: UIN Sumatera Utara, 2016, hlm. 33.

Sugiyono. (2011). Metode Penelitian Pendidikan: Pendekatan Kuantitatif, Kualitatif, $R$ dan D. Bandung: Alfabeta.

Syukri Zarkasyi, Abdullah. (2005). Gontor dan Pembaharuan Pendidikan Pesantren. Jakarta: PT RajaGrafindo.

Syukri Zarkasyi, Abdullah. (2005). Manajemen Pesantren (Pengalaman Pondok Modern Gontor), Gontor: Trimurti Press.

Tim Penyusun PPK. (2016). Konsep dan Pedoman Penguatan Pendidikan Karakter Tingkat Sekolah Dasar dan Sekolah Menengah Pertama. Jakarta:Kementerian Pendidikan dan Kebudayaan Republik Indonesia (Pdf).

Y. Suyitno. (2009). Tokoh-tokoh Pendidikan Dunia (Dari Dunia Timur, Timur Tengah dan Barat). Sekolah Pascasarjana UPI Bandung (pdf). 